\title{
Use of Formative Feedback to Enhance Summative Performance
}

\author{
Christian Cobbold
}

Griffith University, School of Medicine, Australia,c.cobbold@griffith.edu.au

\section{Louise Wright}

Griffith University, School of Medicine, Australia, louise.wright@griffith.edu.au

\begin{abstract}
There is increasing literary evidence for the design of robust formative feedback in higher education. Translation of theoretical models into practice is still evolving and much of the available evidence is based on participant perceptions rather than quantitative changes in learning outcome. Students are often dissatisfied with standard modes of feedback and their perceptions often do not align with that of teachers who feel that students may undervalue the feedback. Standard feedback tends to give limited information that focuses on the assessment product and does not engage students in learning processes. Formative feedback that has been purposefully designed to scaffold student learning is theoretically more effective, especially with closure of the learning loop. This study quantitatively evaluated the effectiveness of well-designed, fit for purpose formative feedback provided to biomedical science students on their draft assignments before summative submission. Student outcome data from feedback and non-feedback groups for the performance during an assignment, a module and the year of study were analysed using a paired t-test. Students submitting a formative draft and receiving formative feedback for their assignment achieved significantly better summative outcomes for both the assignment and module than students who did not. Educational theory of effective feedback design was put into practice and shown to positively affect educational outcome for students in this module.
\end{abstract}

Keywords: feedback, formative, summative, assessment, draft

\section{INTRODUCTION}

There is a growing body of research literature that demonstrates the effectiveness of formative feedback on student assessments in supporting higher educational progression (Juwah, MacfarlaneDick, Matthew, Nicol \& Smith, 2004; Nicol \& Macfarlane-Dick, 2006, Hattie \& Timperley, 2007), although there is still a need for empirical demonstration that well-designed formative feedback achieves this in practice (Jackel, Pearce, Radloff \& Edwards, 2017). The most effective formative feedback modifies student thinking to affect improved learning (Shute, 2008) and should consider the context and the level of the learner (Brown \& Race, 2012). However, with increasing student numbers and limited staff time, this extent of formative feedback is often difficult to achieve. There is also a lack of alignment between staff and student perceptions of feedback (Walker \& Hobson, 2014) and although students tend to seek feedback it may be negatively received or poorly applied (MacDonald, 1991; Price, O’Donovan \& Rust, 2007; Sinclair \& Cleland, 2007). There are many barriers to the uptake of feedback, including student appreciation of the feedback itself and the ability to make judgements (Carless \& Boud, 2018). Ideally, students should understand the purpose of their assessment and be able to judge their own work (Smith, Worsfold, Davies, Fisher \& McPhail, 2013). Good feedback should comprise instructional guidance with cues for improvement, rather than provision of direct correction (Hattie \& Timperley, 2007). A structure that is brief, poorly focused or easily misinterpreted (Nicol \& Macfarlane-Dick, 2006; Stern \& Solomon, 2006) fails to enable student

Citation: Cobbold, C., \& Wright, L. (2021). Use of Formative Feedback to Enhance Summative Performance. Anatolian Journal of Education, 6(1), 109-116. https://doi.org/10.29333/aje.2021.619a 
understanding and adds an additional barrier to effective learning. Many academics do not provide the type of fit for purpose feedback to stimulate higher level critical thinking (Turnitin, 2012), and instead they provide a more standard form of feedback focussing on writing style and spelling (Stern \& Solomon, 2006). Poor feedback can also be confusing for students, set unrealistic goals or be too complicated and consequently the student may not apply it or misapply it resulting in decreased assignment quality (Stern \& Solomon, 2006). Although academics generally recognise the usefulness of formative feedback, the understanding of feedback quality is variable. Orsmond and colleagues (2013) warn against standard feedback formats in favour of newer structures that encourage teacherstudent dialogue, encourage self-regulation, feedback on process and proactivity. Summative feedback is more universally practiced than formative feedback. Summative feedback addresses only the summative perfomance of students and not the potential direction of subsequent student work (Connors \& Lunsford, 1993; Stern \& Solomon, 2006).

\section{Research purpose:}

Student assignment grades were analysed in order to evaluate the effectiveness of voluntary fit for purpose, structured formative feedback in promoting higher student achievement.

As the design of the assignment had been improved in other respects it was decided to compare the performance of students electing to receive formative feedback with students who did not receive formative feedback within the same student population rather than comparing current student grades with those of previous years. The assessment content, rubric and other module components were the same for students receiving and not receiving formative feedback. To explore the effect of formative feedback on student attainment more broadly the module grades of students receiving feedback was compared with those of students who did not, and the final grades for the entire year of study were also compared for both groups.

\section{METHOD}

\section{Design}

A human pathophysiology module in a Bachelor of Biomedical Sciences programme was evaluated in compliance with university recommendations and redevelopment requested to improve student performance. Aspects of the module were subsequently redesigned including an assessment item, the existing marking rubric (Appendix) and the development of a constructivist formative feedback plan.

The assignment was redesigned for increased relevance and authenticity and involved student construction of a health information brochure or lay summary about one disease-related pathogen from a list choice of ten pathogens. The formative feedback was designed to provide clear, timely, written authentic appraisal and guidance to students (Gibbs \& Simpson, 2004) in conjunction with a filled formative rubric. Students were encouraged to communicate with the academic regarding their feedback and to be proactive in their self-assessment and assignment adjustments (Orsmond, Maw, Park, Gomez \& Crook, 2013). The same academic marked the formative draft and summative submission to the same rubric and all students received a completed summative rubric and assignment grade to close the learning loop, an aspect of design often missing from current published literature (Donovan, 2014). Students receiving both a formative and summative rubric were encouraged to compare the two.

\section{Participants}

Sixty-seven second year students were enrolled in the revised module and all were invited to submit a draft of their written assignment that was worth $10 \%$ of the final module grade. Draft submission was not compulsory. Students electing to submit a draft received structured, formative feedback (the 
submission group) and those not electing to submit a draft did not receive formative feedback (the non-submission group).

The marking criteria and assignment instructions were provided to students at the commencement of the assignment. Drafts were returned to the submission group two weeks after receipt with individualised written formative feedback. This comprised explanations of the positive aspects of work to date, provision of constructive points on clarity, detail, content and reminded the student of learning aims with the aid of the rubric.

All feedback was provided by the academic who would be marking the final summative assignment and both the draft and summative assignment were marked in a manner that blinded the marker as to the identity of each student to eliminate potential bias. Two weeks after the formative feedback the final assignments were submitted by all students and marked according to the same marking criteria with the aid of the relevant rubric (Appendix). All students received an assignment grade and a filled rubric for their final summative submissions as per the standard summative feedback practice for the module.

\section{Data collection and analysis}

Data were quantitative. The final summative assignment grade, the completed module grade and the overall grade for the entire year's work across all 8 modules were accessed via the University grading system. Grades are expressed as a percentage of the total available marks, with $40 \%$ being the pass mark for the module and year.

The data were analysed by comparing the submission group $(n=48)$ and non-submission group $(n=19)$ results for the assignment, across the final module grade and the mark for the entire year (\% in each case). All data were normally distributed, two groups were drawn from the same base population with different conditions imposed and there were more than 15 participants in the smallest group. The data were therefore analysed using paired t-test (Microsoft Excel) for parametric data. The mean and standard error of the mean (SEM) were compared across groups. Results were considered significant if $\mathrm{p}<0.05$.

\section{FINDINGS}

Sixty-seven students were enrolled in the module and completed the assignment, $72 \%(\mathrm{n}=48)$ were in the submission group and $28 \%(\mathrm{n}=19)$ were in the non-submission group.

Student performance as determined by final assignment grade was significantly higher for the submission group (mean mark 67\%, SEM +/- 5.0; Table 1 and Figure 1, Panel A) compared with the non-submission group (mean mark 61\%, SEM +/- 3.0; p <0.0001).

Students in the submission group also had significantly higher marks in the overall module grade (mean grade 62\%, SEM +/- 8.3; Table 1 and Figure 1, Panel A) than the non-submission group (mean grade $57 \%$, SEM +/- 7.2; $\mathrm{p}<0.05)$.

A comparison of the student grade at the end of the year was performed (Table 1 and Figure 1, Panel B). The submission group achieved a higher mean grade (mean year grade $62.5 \%, \mathrm{SEM}+/-7.3$ ) than the non-submission group (mean year grade 58.5,SEM +/- 8.7) for the year, although this result was not statistically significant $(\mathrm{p}>0.05)$. 
Table 1

Comparison of grades (\%) between students who submitted a draft assignment (submission group) and those who did not submit a draft assignment (non-submission group). Columns 2 - 7: Summative achievement on final assignment submission and overall module Columns 8 - 10: Summative achievement on total year grade

\begin{tabular}{|c|c|c|c|c|c|c|c|c|c|c|}
\hline & 1 & 2 & 3 & 4 & 5 & 6 & 7 & 8 & 9 & 10 \\
\hline & $\mathrm{N}$ & $\begin{array}{l}\text { Module } \\
\text { assignmen } \\
\text { t mean } \\
(\%)\end{array}$ & $\begin{array}{l}\text { Module } \\
\text { assignment } \\
\text { SEM }\end{array}$ & $\begin{array}{l}\text { P value } \\
\text { (Assignmen } \\
\text { t mark) }\end{array}$ & $\begin{array}{l}\text { Module } \\
\text { mean }(\%)\end{array}$ & $\begin{array}{l}\text { Modul } \\
\text { e SEM }\end{array}$ & $\begin{array}{l}\text { P value } \\
\text { (Modul } \\
\text { e } \\
\text { mark) }\end{array}$ & $\begin{array}{l}\text { Mean } \\
\text { overall } \\
\text { year } \\
\text { mark } \\
(\%)\end{array}$ & $\begin{array}{l}\text { Year } \\
\text { mark } \\
\text { SEM }\end{array}$ & $\begin{array}{l}\mathrm{P} \\
\text { value } \\
\text { (Year } \\
\text { mark) }\end{array}$ \\
\hline $\begin{array}{l}\text { Draft } \\
\text { submitted }\end{array}$ & 48 & $\begin{array}{l}67.0 \\
(56-80)\end{array}$ & 5.0 & \multirow[b]{2}{*}{$<0.0001$} & $\begin{array}{l}61.9 \\
(43-76)\end{array}$ & 8.3 & \multirow{2}{*}{0.017} & $\begin{array}{l}62.5 \\
(48- \\
75)\end{array}$ & 7.3 & \multirow{2}{*}{ NS } \\
\hline $\begin{array}{l}\text { No draft } \\
\text { submitted }\end{array}$ & 19 & $\begin{array}{l}61.1 \\
(56-66)\end{array}$ & 3.0 & & $\begin{array}{l}56.7 \\
(41-66)\end{array}$ & 7.2 & & $\begin{array}{l}58.5 \\
(37- \\
70)\end{array}$ & 8.7 & \\
\hline
\end{tabular}

Panel A

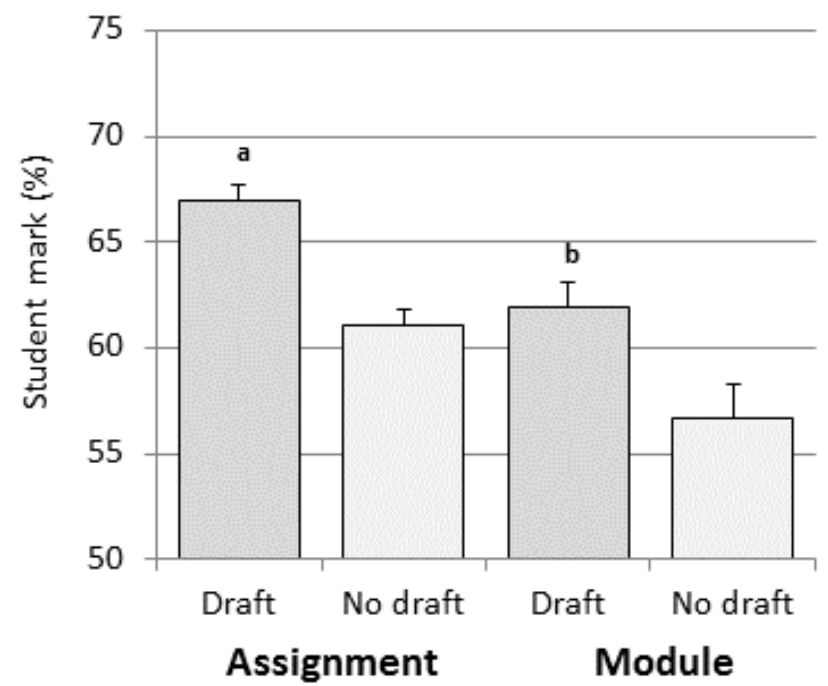

Panel B

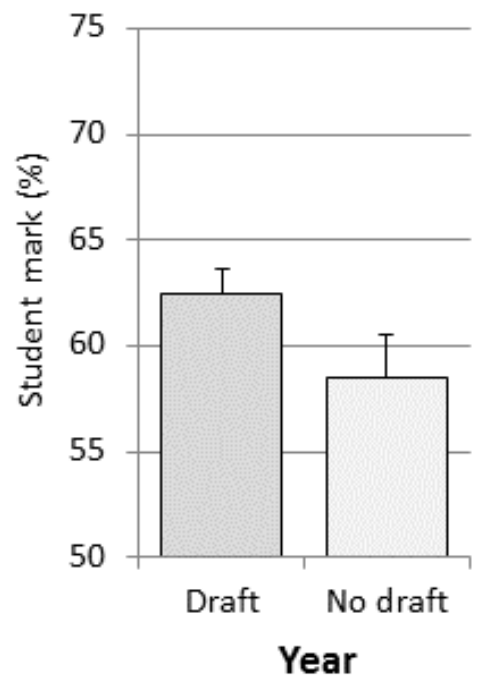

Figure 1

Comparison of grades (\%) across assignment and module (Panel A: a and b respectively) and year grade (Panel B) for the submission group (dark shading) and the non-submission group (light shading). 'a' denotes a significantly higher assignment grade for students who submitted a draft than those who did not submit a draft $(\mathrm{p}<0.0001)$; ' $\mathrm{b}$ ' denotes significantly higher overall module grade for students who submitted a draft than those who did not submit a draft $(\mathrm{p}<0.05)$ 


\section{DISCUSSION}

This study evaluated the effect on student grades of provision of fit for purpose formative feedback on draft assignments before final assessment submission. The feedback was constructed specifically for the content, context and level of the students and informed by the assignment and module design and outcomes (Brown \& Race 2012). The students who submitted a draft assignment and received fit for purpose formative feedback achieved significantly better summative assignment grades than those who did not. This is consistent with other studies showing student performance improvement with constructive formative guidance (Juwah, Macfarlane-Dick, Matthew, Nicol \& Smith, 2004; Orsmond, Merry \& Reiling, 2005; Walker \& Hobson 2014).

The students who received formative feedback also achieved higher module grades than the nonsubmission group. It could be argued that the submission group contained more highly motivated students who were inherently more likely to seek and use feedback (Sinclair \& Cleland, 2007) and therefore more likely to perform well in general. However, the formative feedback design for the assignment addressed the learning process rather than the assignment product and also aimed to foster student self-regulation for learning (Orsmond, Maw, Park, Gomez \& Crook, 2013). It therefore probable that the encouragement of broader learning within the topic area, the fostering of student selfassessment and development of greater understanding of feedback helped the submission group students to learn across the whole module.

The submission group also recorded a numerically higher mean grade than the non-submission group for the whole year ( 8 modules) although this was not statistically significant. This suggests that the topic specific improvement was stronger than general improvement, although the number of students studied was small and the feedback only integrated to one assessment. Hughes and colleagues have noted that modularisation may limit feedback within the module topic area and improvements within a module may not necessarily facilitate student progression towards whole program level outcomes (Hughes, Smith, \& Creese, 2015). Some authors propose the use of student exemplars, student assessment of old peer drafts and continuous peer assessment to introduce feed forward elements that may provide students with skills transferable to modules on different topics (Scoles, Huxham \& McArthur, 2012; Carless \& Boud, 2018).

Students are not always sure how best to apply standard feedback (Still \& Koerber, 2010) that comprises isolated symbols e.g. question marks, directive comments e.g.' 'rewrite' (Weaver, 2006) and is unhelpful and frustrating for students (Williams, 1997). Previous research has explored the benefits of strong feedback design (Gibbs \& Simpson, 2004) and that feedback language can be used differently to variably impact student application. Colthorpe and colleagues noted that use of isolated single words did not provide effective feedback, whereas the addition of detail effected positive student changes (Colthorpe, Liang, \& Zimbardi, 2013). Boud \& Malloy (2013) point out that feedback can only be said to have occurred if there is some discernable change in student outcome. The specific, detailed feedback in this study was designed within a constructivist module to meaningfully encourage deep learning (Higgins, Hartley \& Skelton, 2002) rather than simply to address the superficial language attributes of student work (Stern \& Solomon, 2006; Underwood, 2008; Turnitin, 2012) and did effect improved outcomes for students receiving it. There are also examples where seemingly appropriate feedback does not achieve the desired effect, for example, if a student cannot understand it or deems it too time consuming to apply (Stern \& Solomon, 2006; Colthorpe, Liang, \& Zimbardi, 2013) and the level of student feedback literacy is one of the potential barriers to the uptake of even well-designed formative feedback (Carless \& Boud, 2018).

In an era of increasing student numbers and paucity of academic time, it is difficult to design and implement robust feedback (Brown, 2007). Nevertheless, as this study demonstrates, students do 
benefit from the provision of descriptive, fit for purpose feedback. As good educators we strive to provide education that modifies student thinking and behaviour positively and fosters generalised learning improvement and good formative feedback enables this (Shute, 2008). Further developments for the modularised program in this study, and others like it, would be to include constructive formative feedback into more assignments across the program and to trial the use of exemplars and peer assessment to develop student feedback literacy more generally and foster this transferable skillset to other modules within the program.

\section{REFERENCES}

Boud, D., \& Molloy, E. (2013). Rethinking models of feedback for learning: The challenge of design. Assessment and Evaluation in Higher Education, 38, 698-712. http://doi.org/10.1080/02602938.2012.691462

Brown, L. V. (2007). Psychology of motivation. Hauppauge, N.Y: Nova Science Publishers.

Brown, S., \& Race, P. (2012). Using effective assessment to promote learning. In Hunt, L. and Chalmers, D. (eds.), University Teaching in Focus: A Learning Centred Approach . London: Routledge, Taylor and Francis Group, pp. 74-91.

Carless, D., \& Boud, D. (2018). The development of student feedback literacy: enabling uptake of feedback. Assessment and Evaluation in Higher Education, 43, 1315-1325. https://doi.org/10.1080/02602938.2018.1463354

Colthorpe, K., Liang, S., \& Zimbardi, K. (2013). Facilitating timely feedback in the biomedical sciences. International Journal of Innovation in Science and Mathematics Education, 21, 60-74.

Connors, R., \& Lunsford, A. (1993). Teachers Rhetorical Comments on Student colPapers. College Composition and Communication, 44, 200-223.

Donovan, P. (2014). Closing the feedback loop: Physics undergraduates' use of feedback comments on laboratory coursework. Assessment and Evaluation in Higher Education, 39, 1017-29. http://doi.org/10.1080/02602938.2014.881979

Gibbs, G., \& Simpson, C. (2004). Conditions under which assessment supports students' learning. Learning and Teaching in Higher Education, 1, 3-31.

Hattie, J., \& Timperley, H. (2007). The power of feedback. Review of Educational Research, 77, 81112.

Higgins, R., Hartley, P., \& Skelton, A. (2002). The Conscientious Consumer: Reconsidering the role of assessment feedback in student learning. Studies in Higher Education, 27, 53-64. DOI: https://doi.org/10.1080/03075070120099368

Hughes, G., Smith, H., \& Creese, B. (2015). Not seeing the wood for the trees: developing a feedback analysis tool to explore feed forward in modularised programmes. Assessment and Evaluation in Higher Education, 40, 1079-1094. DOI: https://www.tandfonline.com/doi/full/10.1080/02602938.2014.969193

Jackel, B., Pearce, J., Radloff, A., \& Edwards, D. (2017). Assessment and Feedback in Higher Education: A Review of Literature for the Higher Education Academy. Retrieved 30 June 2020, from https://research.acer.edu.au/higher_education/53. 
Juwah, C. D., Macfarlane-Dick, B., Matthew, D., Nicol, D. \& Smith, B. (2004). Enhancing student learning through effective formative feedback. Retrieved 30 June 2020, from https://www.heacademy.ac.uk/sites/default/files/resources/id353_senlef_guide.pdf.

MacDonald, R. B. (1991). Developmental students' processing of teacher feedback in composition instruction. Review of Research in Developmental Education, 8, 1-5.

Nicol, D. J., \& Macfarlane-Dick, D. (2006). Formative assessment and self-regulated learning: A model and seven principles of good feedback practice. Studies in Higher Education, 31, 199-218.

Orsmond, P., Maw, S.J., Park, J.R., Gomez, S., and Crook, A.C. (2013) Moving feedback forward: Theory to practice. Assessment and Evaluation in Higher Education, 38, 240-252. http://doi.org/10.1080/02602938.2011.625472

Orsmond, P., Merry, S., \& Reiling, K. (2005). Biology students' utilization of tutors' formative feedback: a qualitative interview study. Assessment and Evaluation in Higher Education, 30, 369-386.

Price, M., O’Donovan, B., \& Rust, C. (2007). Putting a social-constructivist assessment process model into practice: building the feedback loop into the assessment process through peer review. Innovations in Education and Teaching International, 44, 143-152.

Scoles, J., Huxham, M \& McArthur, J. (2012). No longer exempt from good practice: using exemplars to close the feedback gap for exams. Assessment and Evaluation in Higher Education, 38, 631-645.

Sinclair, H. K., \& Cleland, J. A. (2007). Undergraduate medical students: who seeks formative feedback? Medical Education, 41, 580-582

Shute,V.J. (2008) Focus on formative feedback. Review of Educational Research 78;1, 153-189

Smith, C.D., Worsfold, K., Davies, L., Fisher, R., \& McPhail, R. (2013). Assessment literacy and student learning: The case for explicitly developing students "assessment literacy". Assessment and Evaluation in Higher Education, 38, 44-60. http://doi.org/10.1080/02602938.2011.598636

Stern, L. A., and Solomon, A. (2006). Effective faculty feedback: The road less traveled. Assessing Writing, 11, 22-41

Still, B., and Koerber, A. (2010). Listening to students: A usability evaluation of instructor commentary. Journal of Business and Technical Communication, 24, 206-233

Turnitin. (2012). From the margins: What instructors say on student papers - 30 million insights into improving instructor feedback. Turnitin White Paper. Retrieved 30 June 2020, from http://www.turnitin.com/en_us/resources/white-papers

Underwood, J. S. (2008). Effective feedback: guidelines for improving performance. Proceedings of the $8^{\text {th }}$ International Conference for the Learning Science, 2, 415-422

Walker, S., \& Hobson, J. (2014). Interventions in teaching first-year law: Feeding forward to improve learning outcomes. Assessment and Evaluation in Higher Education, 39, 326-38. http://doi.org/10.1080/02602938.2013.832728

Weaver, M. R. (2006). Do students value feedback? Student perceptions of tutors' written responses. Assessment and Evaluation in Higher Education, 31, 379-394 
Williams, S. E. (1997). Teachers' Written Comments and Students' Responses: A Socially Constructed Interaction. Paper presented at the Annual Meeting of the Conference on College Composition and Communication (48th,Phoenix, AZ, March 12-15, 1997). Retrieved 18 December 2020, from https://files.eric.ed.gov/fulltext/ED408589.pdf 